\title{
Perindopril Erbumine
}

National Cancer Institute

\section{Source}

National Cancer Institute. Perindopril Erbumine. NCI Thesaurus. Code C47666.

The tert-butylamine salt of perindopril, the ethyl ester of a non-sulfhydryl ang iotensin converting enzyme (ACE) inhibitor with antihypertensive activity. Upon hydrolysis, perindopril erbumine is converted to its active form perindoprilat, inhibiting ACE and the conversion of angiotensin I to angiotensin II; consequently, ang iotensin II-mediated vasoconstriction and angiotensin II-stimulated aldosterone secretion from the adrenal cortex are inhibited and diuresis and natriuresis ensue. 